\title{
Evaluering van Saamgestelde- en Standaardslytvaste plate op Laaibakke van Hidrouliese Voorlaaiers in Platinummyne
}

\begin{abstract}
Outeurs:
Witske le Roux

Tamba Jamiru

Lodewyk Willem Beneke

Taoreed Adesola Adegbola

Affiliasie:

Departement van Meganiese en Megatroniese Ingenieurswese, Tshwane Universiteit van Tegnologie

Korresponderende outeur: Witske le Roux

Epos: witskelr@gmail.com

Datums:

Ontvang: $\quad$ 20/04/21

Aanvaar: $\quad 31 / 08 / 21$

Gepubliseer: 19/10/21

Hoe om hierdie artikel aan te haal:

Witske le Roux, Tamba Jamiru, Lodewyk Willem Beneke, Taoreed Adesola Adegbola, Evaluering van Saamgestelde- en Standaardslytvaste plate op Laaibakke van Hidrouliese Voorlaaiers in Platinummyne, SuidAfrikaanse Tydskrif vir Natuurwetenskap en Tegnologie 40(1) (2021). https://doi.org/10.36303/ SATNT.2021.40.1.852

An English copy of this paper is available online at http://www.satnt.ac.za/ index.php/satnt/article/ view/852

Kopiereg:

C) 2021. Authors.

Licensee: Die SuidAfrikaanse Akademie vir Wetenskap en Kuns. Hierdie werk is onder die Creative Commons Attribution License gelisensieer.
\end{abstract}

Die artikel gee 'n uiteensetting van die resultate van navorsing wat gedoen is om te bepaal of die gebruik van chroom-karbied (CK) oorlegde voeringplate as 'n alternatief vir slytvaste (SV) plate aanbeveel kan word ter verlenging van die produksiesiklus van hidrouliese voorlaaiers in platinummyne.

Navorsing toon dat slegs 53\% van die RH340 voorlaaiers wat in die myn gebruik word 'n diensperiode van 3500 uur in produksie haal alvorens meganiese herstelwerk genoodsaak word. 'n Alternatiewe voeringplaat met langer diensperiodes kan die produktiwiteit van die meganiese voorlaaierkomponente verhoog terwyl produksie-uitsette en hoë vlakke van doeltreffendheid gehandhaaf word.

Die slytvastheid van saamgestelde CK- en standaard SV-plate is vergelyk deur twee RH340 voorlaaierbakke toe te rus met die onderskeie materiale, waarna die werkverrigting van die twee tipes plate onder normale produksietoestande gemonitor en gedokumenteer is tydens gereelde velddiensinspeksies.

Die geldigheid van die navorsing is eerstens ondersteun deur ' $n$ vergelykende literatuuroorsig van beide materiale. Tweedens is ' $n$ reeks metallurgiese toetse uitgevoer op die twee materiale nà vergelykbare periodes in produksie, insluitend 'n vergelykende slytanalise.

Die evaluering het aangedui dat saamgestelde CK-slytplate duurder is en dat die wagperiode van bestelling tot aflewering langer is, maar dat die CK-slytplaat minder weeg as die SV-slytplate. Die SV-slytplaat in hierdie studie het 3283 ure in produksie voltooi, en die CK-slytplaat 4803 ure.

Die bevindinge van hierdie studie is van toepassing op komponente wat in platinummyne gebruik word, aangesien die slytasietempo van laaibakvoerings beïnvloed word deur die geologiese eienskappe van die las wat dit moet skuif.

Die studieresultate ondersteun die aanbeveling van CK as ' $n$ alternatief tot SV voerings. Verdere navorsing behoort gedoen te word om die plasing en oriëntasie van die CK-plate te optimaliseer.

Sleutelwoorde: Slytvaste (SV) plate, Chroomkarbied slytplate (CK-slytplate), Grondverskuiwingstoerusting (GVT), Slytpakket, Voeringplate, Voorlaaier

Evaluation of Composite and Standard Liner Plates on Hydraulic Face Shovels Operating in Platinum Mines: The article details the results of research determining whether the use of composite liner plates, specifically chromium-carbide overlay (CCO) liner plates could be recommended as an alternative to abrasion-resistant (AR) plates to extend the production cycle of hydraulic face shovels operating in platinum mines.

Research indicates that only 53\% of the RH340 face shovels operating in a platinum mine sustain 3500 hours in production. To comparatively study the performance of the two materials, two RH340 face shovel components were repaired, using the respective materials, after which performance was monitored, documented, and supported by regular field service inspections.

To support the veracity of the observations, both materials were compared in a literature review, substantiated by metallurgical testing, comparative wear analysis and field service analysis of the production performance.

The evaluation indicated that CCO is more expensive, has lengthier delivery times, and weighs less than AR plates. On average, the AR plates maintain 3283 hours in production, while the CCO maintained 4803 hours in production. 
The outcome of this study applies to components operating specifically in platinum mines in the Limpopo Province, since the wear rate of a material is influenced by geological content.

An alternative liner plate could potentially increase component productivity, maintaining high-efficiency production outputs. The study recommends CCO as an alternative to standard liner plates, however, since this conclusion is based on a single installation, additional research into optimising the placement and orientation of the CCO plates is recommended.

Keywords: abrasion-resistant (AR), chromium-carbide overlay (CCO), ground engaging tools (GET), wear packages, liner plates, face shovel

\section{Inleiding}

Njini (2020) dui aan dat die Suid-Afrikaanse platinummynbedryf in 2019 'n bydrae van $8 \%$ tot die bruto binnelandse produk (BBP) gemaak het en $75 \%$ van die wêreld se platinum lewer. Elke werknemer in die Suid-Afrikaanse mynbedryf ondersteun ten minste 10 afhanklikes (Njini, 2020).

Een van die operasionele komponente wat gewoonlik op 'n platinummyn gebruik word is 'n voorlaaier, wat 'n meganies-aangedrewe masjien, of 'n aanhegtingstuk of 'n spesifieke komponent kan wees, wat die funksie van grondverskuiwing vervul. Dit is dus 'n tipe grondverskuiwingstoerusting (GVT). Produksietyd wat verlore gaan omdat GVT slyt of breek en dan vervang of herstel moet word is een van die belangrike produksierisiko's in die mynbedryf.

In platinummyne is die tipiese produksielewenssiklus van 'n RH340 voorlaaiervoering, of voeringdele, waarna gesamentlike verwys word as 'n slytasiepakket, ongeveer 2500 uur. Daarna is dit gewoonlik nodig om die slytpakkette te vervang en/of te herstel. Die mynbedryf vereis hoë vlakke van produksie-doeltreffendheid, wat onder andere bereik word deur verlengde produksie-ure van komponente. Om hierdie rede word herstel- en vervaardigingskontrakteurs aangemoedig om produkte te vervaardig of te gebruik met 'n minimum produksieleeftyd van 3500 uur.

Voorlopige navorsing in platinummyne dui aan dat die primêre oorsaak van vervroegde herstel of vervanging van slytpakkette of voerings op die laaibakke van voorlaaiers die oormatige slytasie van strukturele skade aan hierdie komponente is. Dit blyk dat die geabsorbeerde skok van die grond- of rotsmateriaal op die slytpakkette of voerings die belangrikste oorsaak van slytasie en skade is.

Voeringplate word gedefinieer as slytvaste, vervangbare plate wat oormatige slytasie of beskadiging van duur toerusting voorkom deur wrywing tussen die voorlaaierbakke en die grond, rotse, erts of minerale wat verskuif moet word, te verminder of te absorbeer (Precision Grinding, 2016).

Daar is ' $n$ behoefte aan slytpakkette of voerings wat die verlangde 3500 produksie-ure in platinummyne kan handhaaf (Borox Wear Parts (Pty) Ltd, 2020).
RH340 voorlaaierkomponente wat vir die studie oorweeg is, het gemiddeld 3283 produksie-ure gehandhaaf. Komponente wat soveel skade opgedoen het dat dit herstel moes word, het gemiddeld 1791 produksie-ure geneem (Borox Wear Parts (Pty) Ltd, 2020).

Figuur 1 illustreer 'n komponent wat gemerk is vir herstel nà voltooïng van die produksiesiklus in 'n platinummyn (Borox Wear Parts (Pty) Ltd, 2020).

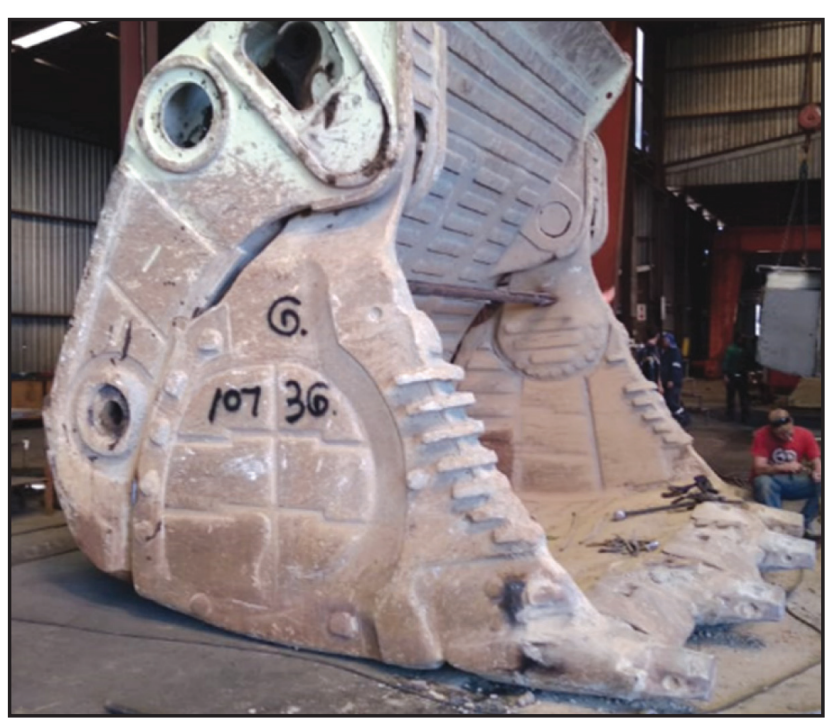

FIGUUR 1: RH340 3G-Komponent (JCB-Gearvest (Pty) Ltd, 2018)

Borox het bevind dat $38 \%$ van die voorlaaierbakke wat met die standaard slytpakket toegerus was en waaraan herstelwerk verrig moes word, skade opgedoen het as gevolg van oormatige slytasie (Borox Wear Parts (Pty) Ltd, 2020).

Slytpakkette vir toerusting wat gebruik word in areas en toepassings met 'n hoë verwagte slytasie tempo, soos sorteer- en breekaanlegte, word vervaardig van gespesifiseerde slyt- en verweringsvaste staaltipes. Sulke staaltipes word algemeen gebruik vir gespesialiseerde funksies in die mynbedryf en verleng die lewensduur van komponente (Borox International AB, 2020).

Barnes et al. sê dat die aanbring van bedekkings of voerings met ' $n$ hoë weerstand teen slytasie en verwering op strategiese sones van komponente, 'n kostedoeltreffende alter- 
natief is vir die grootskaalse vervaardiging van komponente wat geheel-en-al uit weerstandige (en duur) materiale bestaan. Chroomgebaseerde slytpakkette speel 'n primêre rol in mynbou- en verwerkingstoepassings, veral wanneer die lewensduur van komponente produktiwiteit bedreig (Barnes, Borle, Dewar, Andreiuk, \& Mendez, 2014).

Chroomkarbied (CK) is reeds suksesvol gebruik in toepassings met hoë slytasie- of verweringsrisiko's, waar slytasie algemeen en die fisiese skok van die laaivrag op die plate matig is (Waldun, 2020). CK is ideaal vir toepassings waar konvensionele voeringplate nie strawwe werksomstandighede kan weerstaan nie en waar materiaal met 'n hoë skuurvastheid en weerstand teen fisiese skok (impak op die metaal) nodig is (CS Wear Resistatnt Material Co., Ltd, 2020).

In hierdie studie is CK voeringplate as 'n geskikte alternatief vir standaard slytasieplaat (SV-slytplate) geevalueer deur die vergelyking van die dravermoë van die twee tipes plate onder vergelykbare bedryfstoestande.

Die slyt- of voeringplate op 'n komponent moet beskik oor optimale slytvastheid en optimale skokbestandheid, dit wil sê, die vermoë om die fisiese skok en impak van die vrag wat verskuif moet word te absorbeer. Hierdie eienskappe moet ook oor 'n redelike tydperk gehandhaaf word, sodat die voerings die verlangde maksimum lewensduur kan bereik.

Aangesien koste-effektiwiteit en produktiwiteit die belangrikste oorwegings is wanneer ' $n$ komponent herstel of omgeskakel word, moet faktore soos die totale massa van die slytpakket, materiaalkoste en -beskikbaarheid en die duur van herstelwerk, gebalanseer word deur die lewensduur van die slytpakket.

Die studie wat hier beskryf word is ' $n$ vergelykende materiaalondersoek van 'n slytpakket met 'n chroomkarbiedvoering as 'n geskikte of lewensvatbare alternatief vir SV-plate op voorlaaiers in die platinummynbedryf. Die behoefte aan verdere navorsing, indien nodig, sal ook bespreek word.

Materiaal of bronne wat ondersoek of gebruik is in die studie is voorsien of gemagtig deur JCB-Gearvest (Edms.) Bpk. en deur Borox Wear Parts (Edms.) Bpk en sal die eiendom van hierdie maatskappye bly. Etiese oorwegings verseker dat geen materiaal, data, inligting, bronne of resultate wat tydens die studie verkry is op enige manier aangebied of wanvoorgestel sal word om enige van die voeringplaatmateriale doelbewus of onregverdiglik te bevoordeel of te benadeel nie. Voorts sal geen data, inligting of resultate gebruik word om enige gevolgtrekkings of aanbevelings onregverdiglik te ondersteun of te diskwalifiseer nie. Data, inligting en resultate sal ook nie gebruik word om enige wanpraktyke, wanvoorstellings of oneerlikheid te regverdig wat die ingenieursprofessie in 'n swak lig kan stel of daartoe kan lei dat die egtheid van die studie bevraagteken kan word nie.

\section{Metodologie}

'n Gemengde metode van ondersoek is gevolg, met kwantitatiewe sowel as kwalitatiewe tegnieke om die effektiwiteit van beide materiaalopsies tydens produksie te evalueer, ondersteun deur laboratoriumondersoeke. Hierdie benadering is gebruik om subjektiewe en bevooroordeelde gevolgtrekkings te voorkom. Dit verseker die betroubaarheid van die gevolgtrekkings en verhoed dat vooropgestelde idees en konklusies die data of die interpretasie daarvan beïnvloed.

Die woord "produksie" - vir die doeleindes van hierdie studie - beteken die deurlopende operasionele gebruik van die RH340 voorlaaier vir sy doel in 'n platinummyn, en "produksie -ure" sal 'n ooreenstemmende betekenis hê.

Beide komponente wat in hierdie artikel bestudeer is, werk in dieselfde Limpopo platinummyn in Suid -Afrika en werk onder soortgelyke vragte, geologiese inhoud en toestande.

Dit verseker die betroubaarheid van die uitkoms van die studie en voorkom dat vooropgestelde idees en bevooroordeelde gevolgtrekkings die data of die interpretasie daarvan beïnvloed.

\section{Voorlopige Literatuuroorsig}

'n Voorlopige literatuuroorsig is gedoen om bestaande produkte en navorsing, gevolgtrekkings en ervarings van vorige projekte te ondersoek en te verstaan. Dit het insig gegee in moontlike probleme wat verwag kan word en maniere om dit te voorkom of te hanteer.

\section{Vergelyking van Fisiese Produksiewerkverrigting}

JCB-Gearvest (Edms.) Bpk. is gekontrakteer om twee komponente wat uit produksie onttrek is te herstel en te verbeter, ten einde oormatige slytasie en struktuurskade te voorkom. Die twee komponente het in wese dieselfde slytpatrone gehad, maar met verskillende werksomvang.

Die spesifikasies vir herstelwerk, kosteberaming, materiaalen massaspesifikasies van albei komponente is evalueer voordat die herstel- en omskakelingsproses $\mathrm{n}$ aanvang geneem het. Beide komponente is ná herstel teruggeplaas in produksie en met gereelde tussenposes nagegaan. Waarnemings op beide komponente is geboekstaaf om die herstel- en omskakelingskostes in die lig van die produksiewerkverrigtinge te evalueer.

Die voorkaak van die eerste laaibak is beklee met 'n standaard SV-slytpakket en die tweede met'n saamgestelde CK-slytpakket.

Beide voorkake is beklee op sones waar hoë vlakke van slytasie gewoonlik voorkom en op sones waar hoë vlakke van slytasie sowel as 'n medium impak (medium skok) van die laaivrag verwag word. 
Die slytpakkette van beide komponente is met gereelde tussenposes deur dieJCB-Gearvest velddiensbestuurspanne nagegaan, sodat die werkverrigting van die pakkette vergelyk kan word deur middel van visuele waarnemings van die slytasie- en skokpatrone.

\section{Onafhanklike Metallurgiese Laboratorium- toetse}

Die SV- en CK-slytplate is onafhanklik getoets volgens die standaarde en spesifikasies in Tabel 1 hieronder. Hierdie laboratoriumtoetse bied 'n objektiewe stel data aanvulled tot die subjektiewe visuele werkverrigtingwaarnemings tydens produksie. Hierdie objektiewe datastel versterk die verifiëerbaarheid van die studie.

Die chemiese ontleding van die SV -plate is gedoen om te bepaal of die verminderde prestasie toegeskryf kan word aan die koekie -effek of aan enige afwykings van die materiaal- en meganiese eienskappe van die spesifieke materiaal.

Jadco dui aan dat hierdie inkonsekwentheid ook toegeskryf kan word aan die koekie -effek. Hierdie effek word tipies vermoed as 'n SV-slytplaat aanvanklik baie goed presteer en die integriteit tydens die eerste produksiefases behou, maar dan binne 'n paar weke vinnig begin verslyt. Die koekie -effek vind plaas wanneer materiaal nie die korrekte legeringselemente in die regte verhoudings het nie, wat verhoed dat die materiaal deur die hele dikte verhard word. Die resultaat is ' $n$ materiaal wat effektief slegs aan die oppervlak gehard is, wat die middelpunt van die materiaal met materiaaleienskappe nader laat as dié van sagte staal, vandaar die gepaste etiket van die "koekie" -effek (Jadco, 2019).

TABEL 1: Toetsspesifikasies vir die bepaling van eienskappe van materiale

\begin{tabular}{l|l|c|c|c}
\hline$\#$ & Materiaal Toets & Spesifikasies & $\begin{array}{c}\text { TH400 } \\
\text { basismateriaal }\end{array}$ & CK-laag \\
\hline 1. & Brinell hardheidstoets & ISO 6506-1 & $\checkmark$ & $\checkmark$ \\
2. & Kerf-en-impaktoets & ISO 148-1 & $\checkmark$ & \\
3. & Trektoets & ISO 6892-1 & $\checkmark$ & \\
4. & Spektrometriese analise & ISO 6507-1 & $\checkmark$ & $\checkmark$ \\
5. & Mikro-ondersoek & & $\checkmark$ & $\checkmark$ \\
\hline
\end{tabular}

\section{Resultate en bespreking}

\section{Literatuuroorsig}

Die verskillende maniere waarop slytplate faal of swig is in die literatuuroorsig ondersoek. Daar is ook navorsing gedoen oor die invloed van die konfigurasie waarin die komponent gebruik word, byvoorbeeld die graaf- of voorlaaierkonfigurasie, op die hoeveelheid en graad van slytasie. Die bevinding is dat die voorlaaierkonfigurasie meer slytasie meewerk. Aggregates Business het ook bevestig dat die uitbreekkrag geassosiëer met 'n voorlaaierkonfigurasie groter is as die uitbreekkrag van 'n laaigraafkonfigurasie (Aggregates Business, 2012).
Grondverskuiwingskomponente word toegerus met slytpakkette om die produksiesiklus te verleng. SV-slytplate is gewone staalplate met hoër materiaal- en hardheidseienskappe, wat ongeveer vier keer langer hou as hoësterkte standaard staalplate (AZoM, 2018).

'n SV-slytplaat is 'n koolstofstaalplaat, vervaardig deur die toevoeging van koolstof tydens die vormingsproses. Hoewel dit slytvas is, maak die toevoeging van koolstof die plaat meer bros en verminder dit die sterkte van die plaat. Dit is dus geskik vir gebruik in areas waar hoë slytasie verwag word, maar nie vir konstruksie-doeleindes nie (AZoM, 2018).

SV-slytplaat is ' $n$ moderne oplossing vir die vervaardiging en herstel van industriële installasies met 'n hoë slytasie en erosie (Klimpel, Gorka, \& Czuprynski, 2006).

Slytasie -meganismes dra by tot $60 \%$ van die totale slytasieverliese in die mynbou-, hef- en opgrawingsbedryf. In hierdie geval word die slytasieproses beskryf as stootskuur, waar die skuur die verwydering van materiaal van 'n vaste oppervlak behels wanneer dit gelaai word teen deeltjies van dieselfde of groter hardheid (Chintha, 2019).

Deur die hardheid, mikrostruktuur en slytasie-morfologie van Hardox400- en NM400-SV-slytplate se staal te ontleed, is vasgestel dat die slytasie-meganismes van die staal hoofsaaklik manifesteer as skuur- en vermoeidheidskrag (Pei, et al., 2020). Moegheid, put- en slagklere is dra -meganismes wat voorkom by operasies waar komponente blootgestel word aan onderskeidelik gly, rol en slag. Die blootstelling lei tot 'n skielike vernietiging van die oppervlak as gevolg van krake onder die oppervlak wat deur stresfietsry voortplant. Skuur en aanhoudende slytasie is die gevolg van krap deur harde deeltjies wat vasgevang is of uitsteeksels wat uit die paringsoppervlak strek (Varenberg, 2013).

'n CK-slytplaat is 'n buitengewoon harde plaat met bymiddels wat hoë skuur- en slytweerstand bied. Dit word gebruik in sones waar baie slytasie en wrywing verwag word, maar waar lae tot medium skokbreking vereis word. CK-plate is maklik om te installeer en verg minder onderhoud (ASGCO, 2020).

Alle sweislegerings kan met hitte gevorm word sonder verswakking van die slytasieweerstand in die sones waar hitte toegepas word. Tipiese voorbeelde is gebluste en getemperde staal (Welding Alloys Group, 2020).

Die uitdaging is om 'n oorlegkombinasie te ontwerp met weerstand teen sweisskeur en 'n goeie kombinasie van eienskappe; 'n balans is egter nodig, aangesien 'n hoër inhoud en groter groottes karbiede in die oorlaag groter slytasieweerstand sou gee, maar ook 'n hoër skeurtendens, hoër koste en dikwels laer weerstand sou meebring. Geoptimaliseerde deklaagspesifikasies moet 'n redelike hoe- 
veelheid primêre harde fases bevat wat draweerstand bied, terwyl harde deeltjies geoptimaliseer moet word om breek tydens slytasie te voorkom (Jing, Rangasayee, Minghao, \& Leijun, 2020).

Omdat sweislegeringsplate ' $n$ hoë graad van hardheid het en onbuigsaam is, word dit nie aanbeveel dat eindgebruikers probeer om dit self te vorm of te buig nie. Die voorafvorming word die beste gedoen in 'n werkswinkel, met die vorming van die plate loodreg op die sweislasrigting van die oorlegging (Welding Alloys Group, 2020).

In teenstelling met standaard SV-slytplate, waar die oriëntasie van die materiaal 'n ononderskeibare effek op die materiaal se dravermoë het, moet CK-slytplate in lyn gebring word volgens die rigting van die dra. Produkte wat met snyperstegtegnieke gelas is en wat in hoëspoeddeeltiies toegedien word, moet die lasrigting van die oorlaag loodreg op die vloei van skuurmateriaal hê. Vir oscillasie -laskrale kan voorkeur -slytasie in die krale -oorvleuelingsareas gesien word as die oorlegplate geïnstalleer word met die lasrigting parallel met die vloei van die materiaal (Welding Alloys Group, 2020).

\section{Massa-analise van materiale}

Die massa-analise het aangedui dat 'n RH340 voorlaaibak se volledige slytpakket $677,83 \mathrm{~kg}$ ligter sal wees indien dit van saamgestelde CK-materiaal in plaas van die standaard SV-staal gemaak word. Vir berekeninge en ontledingsdoeleindes is die waarde vereenvoudig tot ' $n$ massabesparing van $600 \mathrm{~kg}$. Figuur 2 illustreer die uiteensetting van die materiaalmassa van 'n CK-slytpakket in vergelyking met 'n gewone SV-slytpakket vir die saamgestelde draagplaatkomponent.

Die verskil in massa beteken dat die laaibak ongeveer $5,34 \%$ ligter is as dit uitgevoer word met 'n CK-slytpakket, maar hierdie verskil het min of geen invloed op die dra- of laaivermoë van die komponent.

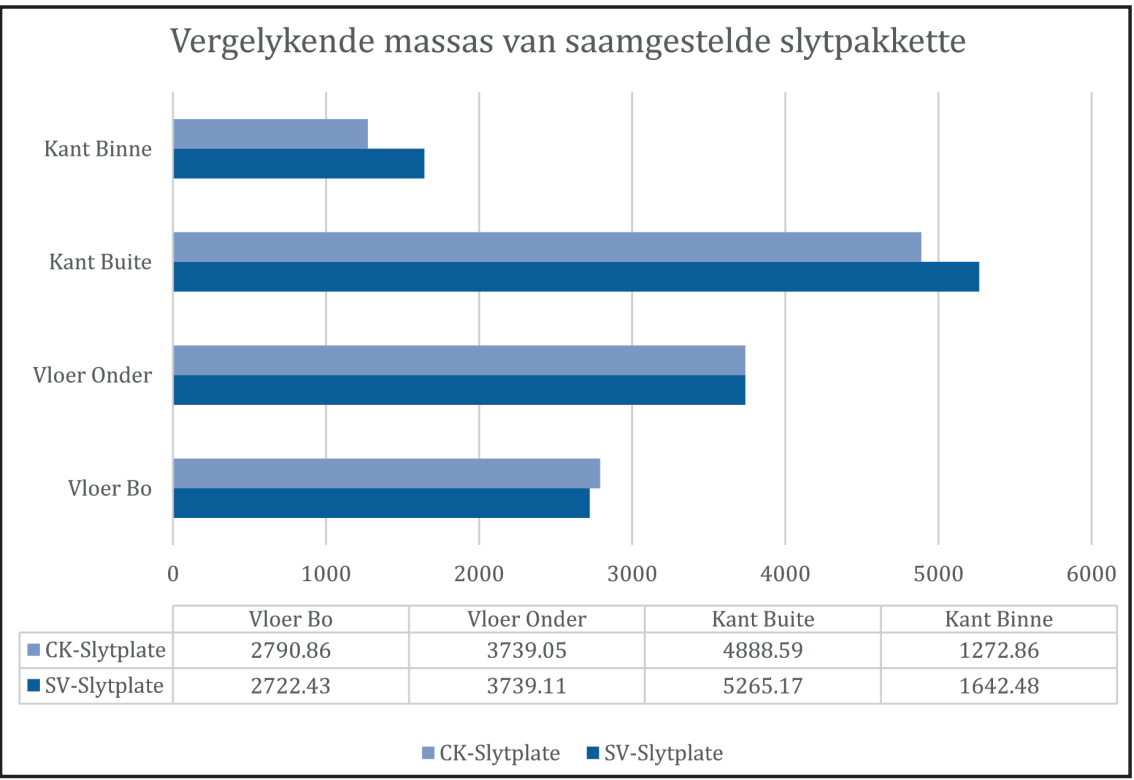

Figuur 3 illustreer die komponente tydens die snyproses, waar die ou SVslytplate verwyder word en die komponente voorberei word vir die nuwe plate. Dit toon ook die omvang van die slytasie wat die komponent tydens produksie opgedoen het.

Waar die SV-plate te veel slytasie opgedoen het, is die struktuur van die komponent, veral op die sywande, blootgestel. Die struktuur van 'n komponent is aansienlik duurder en tydrowend om te herstel.

Indien 'n CK-beklede komponent 'n minimum van 3500 ure diens kan verrig, beteken dit dat 'n bykomende 55

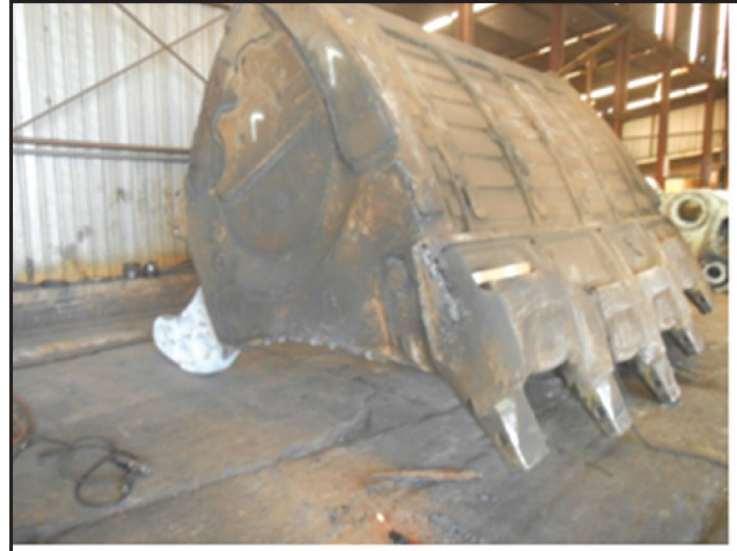

(a)

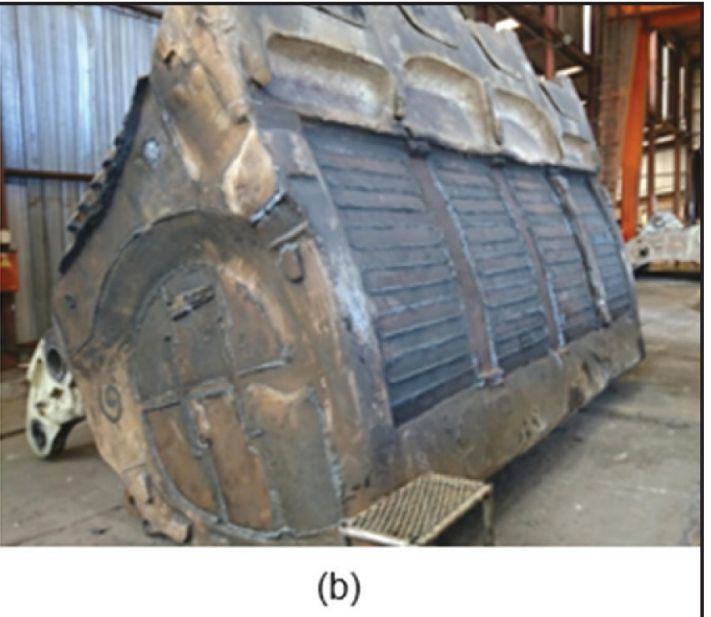

(b)

FIGUUR 3: Komponente voor herstel: (a) Komponent wat met SV-slytplate reggemaak is (b) Komponent wat met CK-slytplate reggemaak is (JCB-Gearvest (Pty) Ltd, 2018). 
146 ton materiaal tydens die lewensduur van die komponent verskuif kan word. Onder optimale toestande kan diebykomendelas'n toename van $10.106 \%$ in produktiwitiet van werksverrigting per komponent in produksie tot gevolg hê.

\section{Materiaalvoorraad}

Alle voorlaaierbakke is onderworpe aan ' $n$ afleweringsdatum van 16 weke vanaf die aankoms van die laaibak in die werkswinkel waar herstelwerk gedoen moet word. Gewoonlik neem dit slegs 12 weke om 'n komponent te herstel vanaf die datum waarop die materiaal vir herstelwerk gelewer word.

Probleme met kwaliteit, vertragings met die lewering van materiale en verbruiksartikels en kragonderbrekings veroorsaak egter 'n verlies aan beskikbare tyd vir herstelwerk. Sulke vertragings kan vinnig ophoop en die addisionele leweringstydperk van 4 weke verkwis. Dit is dus van kritieke belang dat enige materiaal wat bestel word betyds afgelewer word, vervaardig is volgens die goedgekeurde tekeninge en van die verlangde kwaliteit is.

Navorsing het aangedui dat drie tot vier werksdae gewoonlik nodig is om standaardmateriale soos S355J-, 400- en 500-graad slytplate op te sny tot die verlangde mates, ongeag die grootte van die bestelling. Indien buigof vormwerk ook gedoen moet word, duur dit tot 7 werksdae.

Probleme met kwaliteit kom gewoonlik slegs voor as die aangeduide spesifikasies nie gevolg word nie, in so geval die bestelling herbestel maar dit lei egter gewoonlik tot 'n vertraging van 5 werksdae vir die produksiespan.

Gesnyde saamgestelde slytplate met standaardgroottes en spesifikasies vir die deklaagverhouding kan gewoonlik binne drie tot vyf werksdae afgelewer word. CK-slytplaat onderdele wat moet gesny, vorm, en buig word, en wat 'n unieke spesifikasie van die deklaagverhouding het, het 'n afleweringstyd van twaalf werksdae tot twintig werksdae.
As die integriteit van die CK-slytplate in die gedrang kom tydens die vervaardiging van die onderdeel, kan dit die prestasie van die onderdele beïnvloed, wat kan lei tot 'n groter skeuring of delaminasie tydens die produksiesiklus van die komponent.

Dit stem ooreen met wat tydens die produksie gesien is, en word ondersteun deur die metallurgiese ontleding en verslag van die CK-slytplate.

Figuur 4 illustreer die monteringingsproses van die onderskeie slytplate op die komponente. Die CK-slytplate is in blou gemerk en is uniek aan die komponent.

Navorsing het getoon dat die aflewering van CK-slytplate die aanvanklike tydsvertraging met $20 \%$ oorskry het, met 'n totaal van $40 \%$ in vergelyking met die afleweringstyd van standaard SV-slytplate, maar die $40 \%$ materiaalleeftydvertraging hou verband met die herstel en hervervaardiging van gedelamineerde onderdele wat vermy kan word met 'n meer doeltreffende spesifikasie en ontwerp van CK-slytplate tydens toekomstige herstelwerk.

Die tipe saamgestelde CK-slytplate, wat gebruik word in die omhulsel van die komponent in hierdie artikel, het 'n materiaalspesifikasie van $40 \%$ basismateriaal met 'n $60 \%$ deklaag vir die $25 \mathrm{~mm}$-plaat en 'n $43 \%$ tot $57 \%$ oorlaag deposito vir die $30 \mathrm{~mm}$-plaat - dit wyk af van die standaard saamgestelde slytplaat -oorlegverhoudings wat in die onderstaande paragraaf bespreek word, wat toon dat die dikte van die deklaag nie die dikte van die basismateriaal mag oorskry nie, aangesien 'n dikker oor- en basismateriaalverhouding meer geneig om te delamineer tydens vormings- en buigprosesse.

Standaard saamgestelde slytplaat delamineer selde tydens die vervaardiging van die velle. Die standaardblaaie, wat in die literatuuroorsig ondersoek is, is beskikbaar in oorlegkonsentrasies wat nie 'n 50:50 basismateriaal -oorlegverhouding oorskry nie.

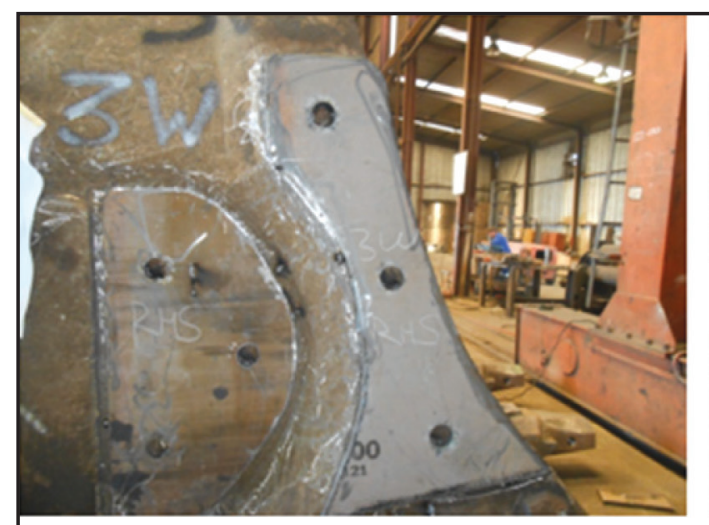

(a)

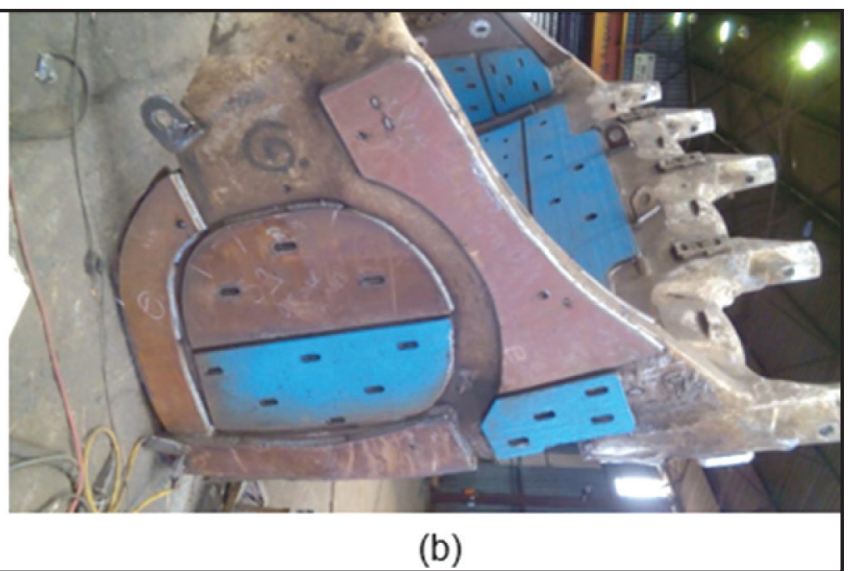

(b)

FIGUUR 4: Montering van slytplate (a) SV-slytplate (b) CK-slytplate(Blou) (JCB-Gearvest (Pty) Ltd, 2018). 
Die studie dui aan dat die sweisprosedures, wat standaard verbruiksgoedere van koolstofstaal spesifiseer, soos ER70S of ER100 wat gebruik word om standaardmateriaal S355J, 400 en 500 -graad materiaal te sweis, nie van toepassing is by die sweis van die saamgestelde CK-slytplate nie. Die standaard koolstoflasprosedures kan slegs gebruik word om die basis van sagte staal te sweis.

In tipiese scenario's bied dit nie 'n probleem nie, maar omdat die spesifikasies van die CK-slytplate afwyk van die standaard samestelling van die samestellende voeringplaat, het die sagte staalbasis te dun geword om die dele voldoende op die struktuur van die voorlaaier te sweis sonder die oorlaag storting wat die lasverbruiksgoedere besoedel. Die aanbevole sweisverbruiksartikels, dit wil sê 307 vlekvrye staal sweisverbruiksartikels, moet gebruik word om die CK-slytplate -onderdele te sweis. Figuur 5 toon die voltooide herstel van die komponent van die CKslytplate aan.

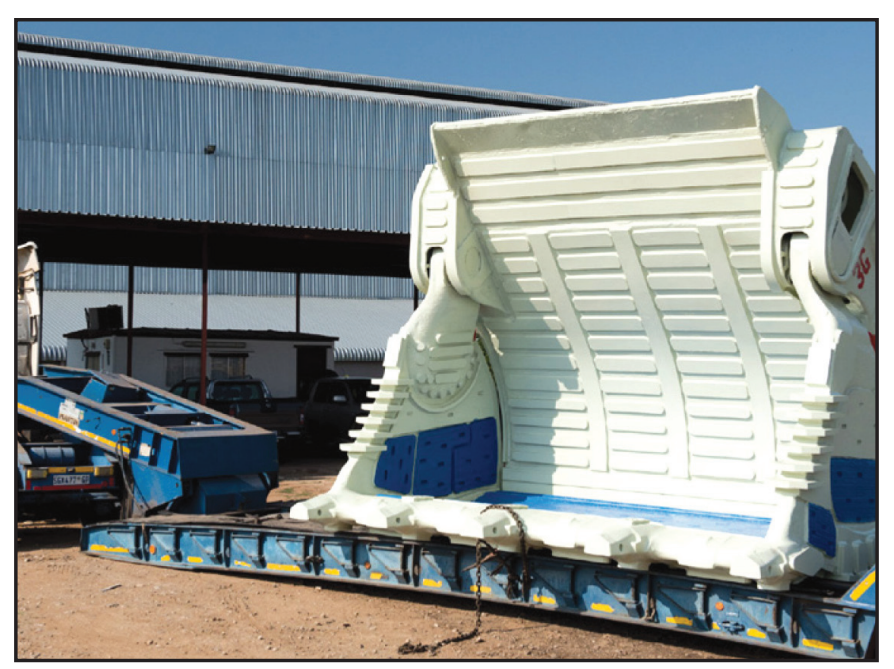

FIGUUR 5: Herstel van RH340 laaibak met saamgestelde CK-slytplate. (JCB-Gearvest (Pty) Ltd, 2020)

\section{Ontleding van produksiewerkverrigting}

Die voorlaaiers wat met onderskeidelik die standaard SVen die saamgestelde CK-slytplate toegerus is, is tydens gereelde velddiensinspeksies ondersoek en waarnemings is geboekstaaf. Hierdie waarnemings was van kritieke belang om die gedrag van die verskillende materiale tydens produksie te bepaal.

Tydens die inspeksies is sones geïdentifiseer wat addisionele slytasie- of skokbeskerming benodig om die laaibakstruktuur te beskerm. Die evaluering het aan die lig gebring dat albei komponente kritieke slytasie opgedoen het wat onttrekking uit produksie genoodsaak het.

Slytasie is as die primêre oorsaak van die swigting van 'n komponent tydens verskillende produksiesiklusfases geïdentifiseer.

Die velddienswaarnemings het aangedui dat die komponent met standaard SV-slytplate aansienlike skade opgedoen het en uit produksie verwyder moes word omdat dele van die slytplate van die vloer van die voorlaaierbak afgebreek het, geillustreer in Figuur 6.

Sou die sweiswerk op die oorblywende vertikale slytplate swig as gevolg van wrywing tussen die plate en die vrag, mag die plate wegtrek van die vloer en die vloerstruktuurplaat van die laaibak blootstel aan skade en slytasie.

Indien die gedeeltelike onklaarraking nie aangespreek word nie, mag dit tot katastrofiese skade aan die laaibak lei, met die gevolg dat die komponent van produksie onttrek sou moes word vir herstel en hervestiging. Die herstelwerk getoon in Figuur 6 het 5 ure geduur, waartydens die myn 'n potensiële 7499,85 ton (1 499,97 t/h) aan produksie verloor het.

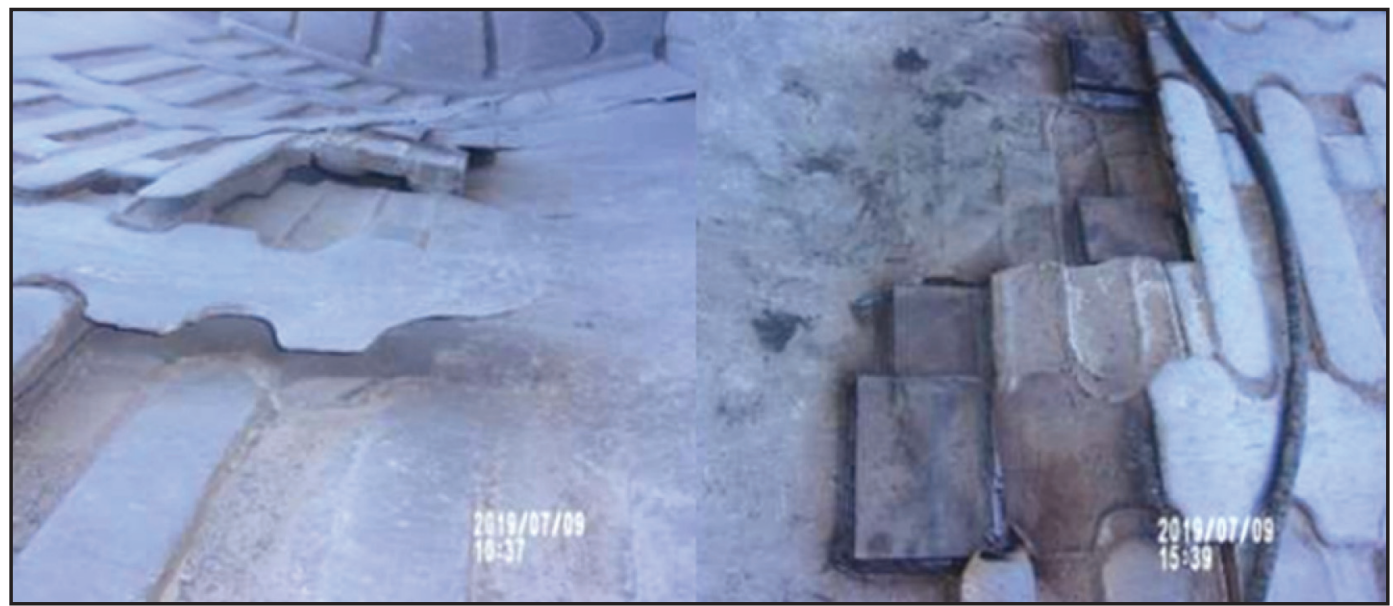

FIGUUR 6: Standaardslytpakket: skade (LK) en herstel (RK). (JCB-Gearvest (Pty) Ltd, 2019). 
Die data-analise van die velddiensverslae het getoon dat die komponent wat met saamgestelde CK-slytplate herstel is (Figuur 7), geleidelik swakker presteer namate die oorlaag begin delamineer en skeur, maar dat geen kritieke onderbrekings met verlies aan produksie nodig was nie.

Tydens die aanvanklike inspeksies het die CK-slytplate goed vertoon en geen tekens van oormatige slytasie of skade weens skok getoon nie. Met verloop van tyd het versplintering van die oorlaag begin en vinnig oor die plaat versprei, maar slegs op slytplate wat in medium-skok- en hoë-slytasiesones gemonteer was.

Die CK-slytplaat wat die vloer van die laaibak volledig bedek het, geilllustreer in Figuur 8, het buitengewoon goed presteer en geen tekens van skade of beduidende slytasie tydens velddienswaarnemings getoon nie.

Toe die CK-slytplate, ontwerp is vir produksie op die platinummyn, was ons nie bewus daarvan dat die oriëntasie van die CK-slytplate so ' $n$ beduidende invloed op die prestasie sou hê nie, maar tydens die literatuuroorsig het dit geword Dit is duidelik dat die CK-slytplate die doeltreffendste is wanneer die sweisraal, of CK-neerslag, loodreg op die rigting waarin die slytasie of skuur aangebring word, geïnstalleer word. Daar is dus 'n potensiaal vir variasie in die prestasie van die CK-slytplate se vermoe om slytasie in produksie te dra totdat die ontwerp van die CK-slytplate geoptimaliseer is en die optimale oriëntasie en plasings van die CK-slytplate ontwikkel en bevestig is. Die geologiese inhoud waarin 'n komponent werk, het 'n direkte invloed op die drameganisme en die dra-tempo van die komponent se slytasieplaat pak, en as sodanig sal die geoptimaliseerde CK-slytplaat ontwerp plekspesifiek wees.

Die oriëntasie van die deklaag op die ontwerp van die CKslytplate op die vloer plaat was loodreg op die rigting van die slytasie, maar dit was nie die geval met die syvoere wat die swakste presteer nie. Dit het duidelik geword dat die oriëntasie en plasing van die CK-slytplate verder verbeter en ondersoek moet word.

Die velddiensanalise het getoon dat die saamgestelde CKslytplate relatief min slytasie toon, veral op die vloer van die laaibak. Aan die binne- en buitemure van die laaibak het die saamgestelde slytplate egter buitengewoon min, indien enige, verdere beskerming teen slytasie gebied sodra die eerste tekens van slytasie voorgekom het.

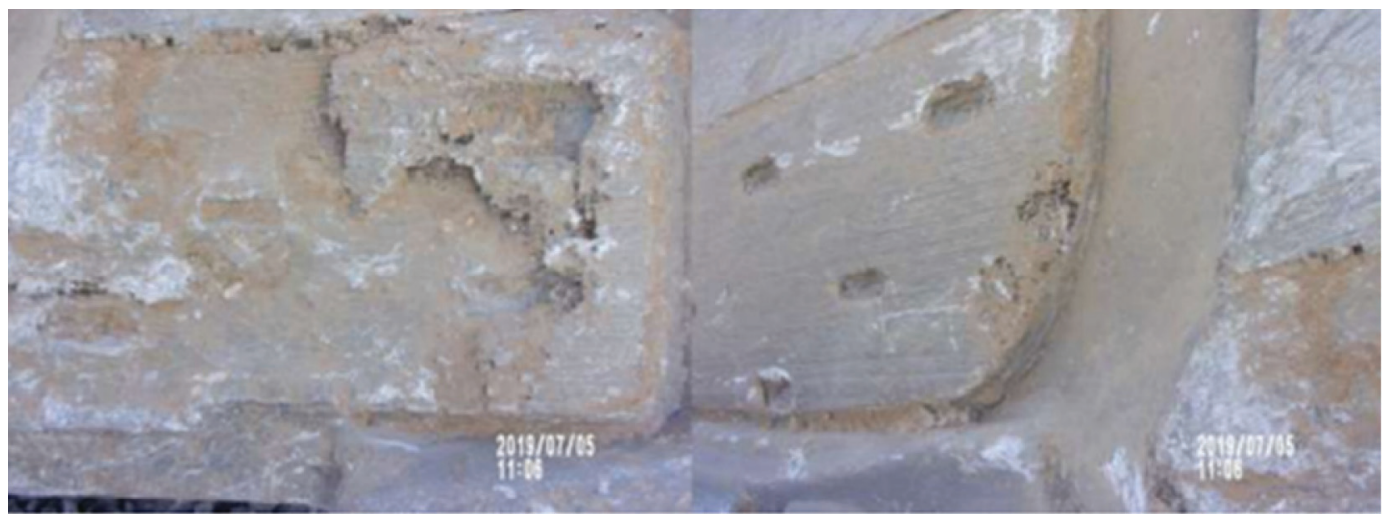

FIGUUR 7: Evaluering van CK-slytplate tydens velddiensinspeksies. (JCB-Gearvest (Pty) Ltd, 2019).

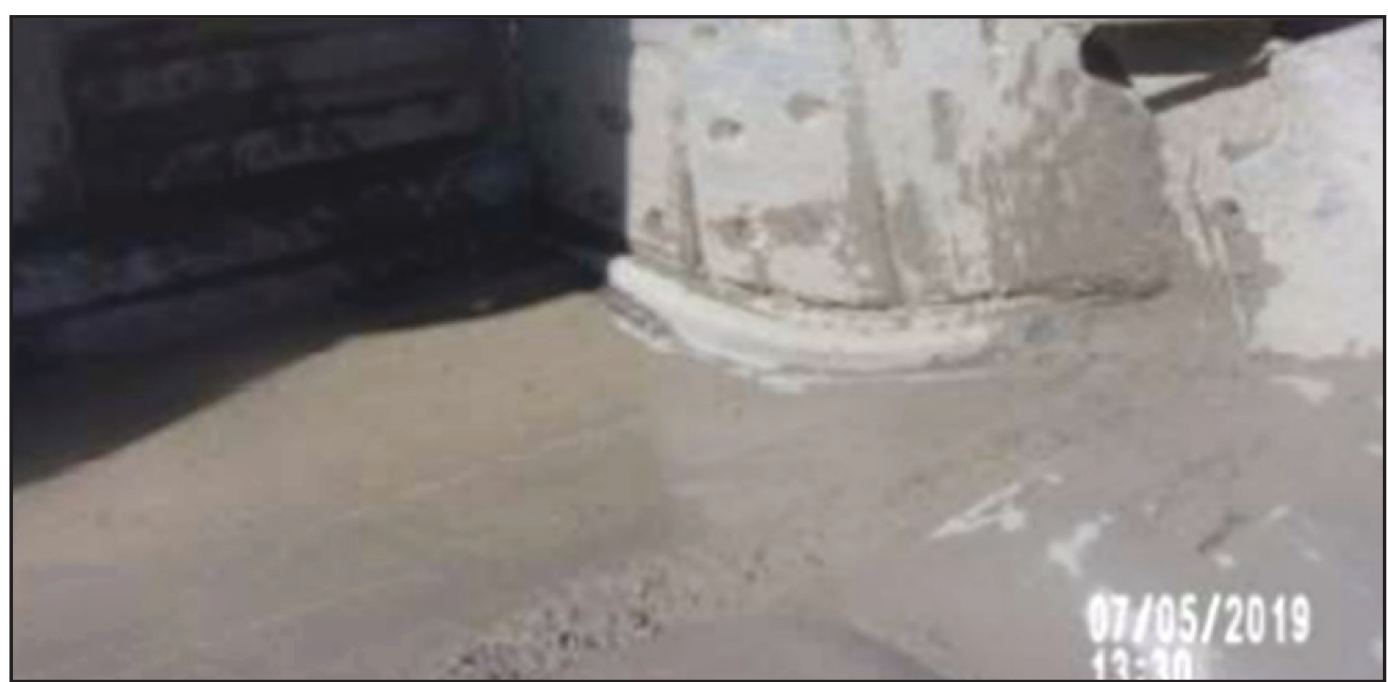

FIGUUR 8: Velddiens CK-slytpakket velddiens evaluering van die binne-vloer (JCB-Gearvest (Pty) Ltd, 2019). 
Navorsing het getoon dat RH340 voorlaaiers toegerus met standaard SV-slytplate ' $n$ verwagte gemiddelde produksielewenssiklus van 3283 uur kan handhaaf (Borox Wear Parts (Pty) Ltd, 2020). Dit is 6,2\% minder as die verlangde minimum aantal ure, wat 'n geskatte produksieverlies van 217 uur tot gevolg het.

Data toon dat 'n voorlaaier 'n gemiddelde produksietempo van $1499,97 \mathrm{t} / \mathrm{h}$ het, met die gevolg dat die produksieverlies van 217 uur per komponent moontlik gelyk aan 'n benaderde produksieverlies van 325493,49 ton tydens die lewensduur van die komponent kan wees. Die totale aantal produksie-ure wat deur die vloerplate bereik is, was 2194 uur, dus $37,30 \%$ laer as die minimum gewenste produksieure.

Figuur 9 illustreer die verwantskap tussen die gemiddelde, minimum en maksimum ure wat die produksie onderhou deur komponente met standaard SV-slytplate in vergelyking met die voorgeskrewe minimum aantal ure en die aantal werksure wat die komponent met CK-slytplate onderhou.

Die komponent met CK-slytplate in die slytasiesones en sekere sones met 'n hoë slytasie, medium-impak, het 4803 uur (Figuur 9, Oranje-T1) in produksie behaal, wat 37\% meer is as die gewenste minimum aantal ure en $46,30 \%$ meer as die gemiddelde RH340 voorlaaier.

Borox het bevind dat ten minste 'n RH340 -komponent wat herstel is met standaard SV-slytplate, met slytasie geïdentifiseer as die primêre oorsaak vir mislukking, slegs 1728 uur (figuur 9, geel - T5) in produksie (Borox Wear
Parts (Edms.) Bpk. , 2020). Dit is ongeveer 50,62\% minder as die verlangde 3500 uur (Figuur 9, Rooi - T3) in produksie. Gemiddeld het 'n RH340 voorlaaier wat met standaard SVslytplate herstel is, ook gemiddeld 3283 uur (Figuur 9, Groen - T4) en 'n maksimum van 4328 uur (Figuur 9, Blou - T2) in produksie (Borox Wear Parts) (Edms.) Bpk., 2020). Ongeveer $9,37 \%$ langer as die gewenste minimum in produksie.

Dit lei tot 2600 uur, byna $250 \%$ verskil tussen die minimum en die maksimum aantal ure wat deur 'n RH340 voorlaaier onderhou word, met standaard slytasieplate herstel word en uit produksie verwyder is omdat slytasie die oorsaak van die mislukking is.

As ons dit in ag neem, het die saamgestelde CK-slytplaat -komponent slegs 10,98\% meer produksie -ure as die standaard -SV-slytplaat-komponent wat die beste presteer het, maar het dit ongeveer $276,35 \%$ meer reggekry as die ergste komponent wat met standaard SV-slytplaat herstel is.

Die verwagting was dat, indien die saamgestelde CKslytplaat die slytasie vir 'n lang tydperk sou kon verduur, die herstel- en hernuwingsbehoefte aan die komponente verminder word, aangesien die CK-slytplaat die struktuurmateriaal voldoende teen skade sou beskerm.

Sodra die komponente hul produksiesiklus voltooi het, is dit geïdentifiseer vir herstel en hervestiging. Die nuwe voorlopige SOW's is ontleed om vas te stel of die saamgestelde CK-slytplaat addisionele beskerming vir die struktuurplaat vereis.

\section{Vergelyking van voorlaaier produksie-ure}

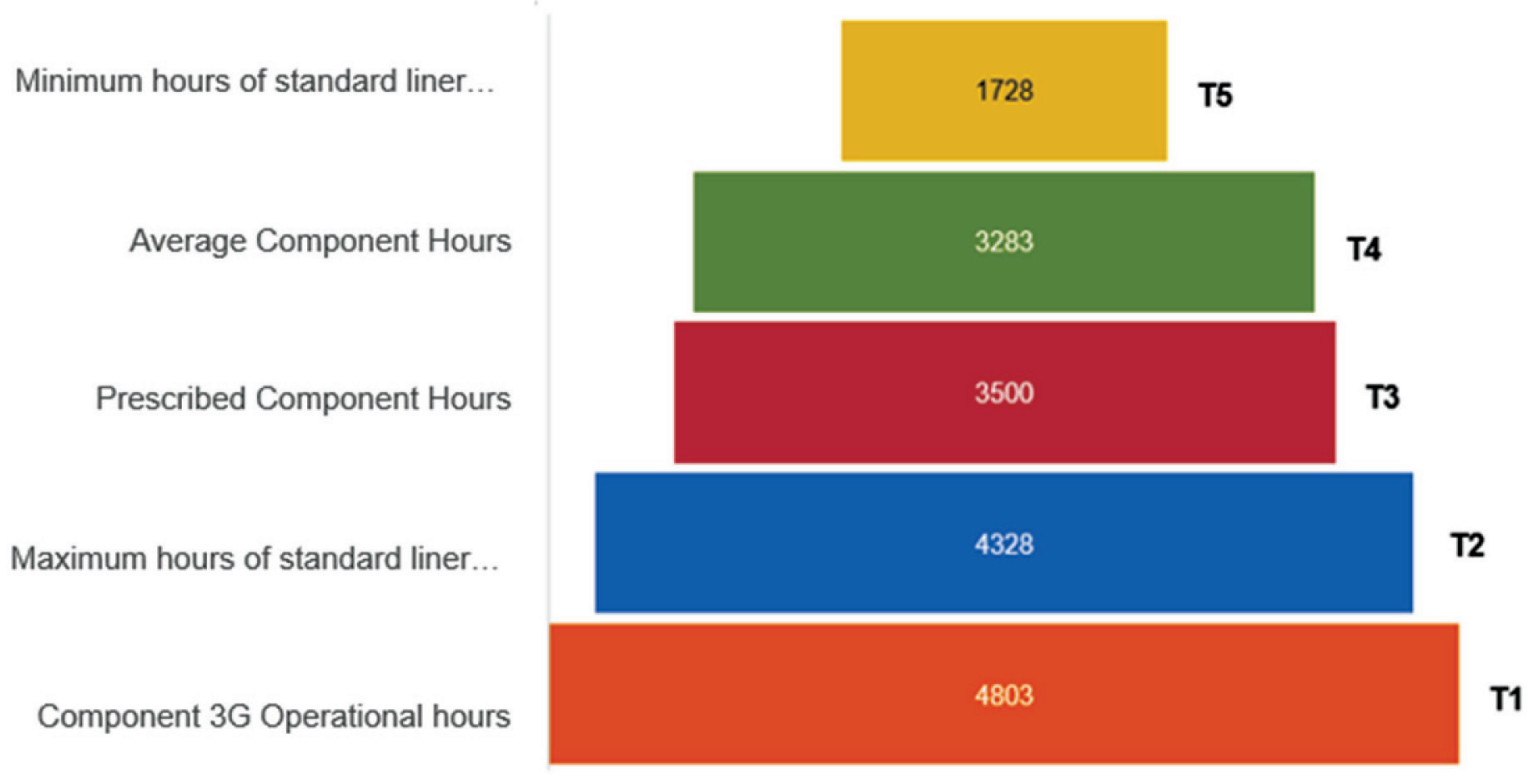

FIGUUR 9: Vergelyking van produksie-ure vir voorlaaiers

(Borox Wear Parts (Pty) Ltd, 2020). 
Die tweede SOW het bevind dat beide komponente ' $n$ volledige voorkaak binne -in die vloer, binne -mure, herstel en buitemuur van die buitekant benodig, en dat die onderste vloer 'n uitgebreide bekleding benodig.

Na voltooiing van 1728 uur in produksie, het die standaard SV-slytplaat RH340 voorlaaier voorkaak 'n geskatte massa van 10 650,95 kg vooraf voorberei (JCB-Gearvest (Edms.) Bpk., 2019), 32,60\% minder as die geskatte materiaal benodig vir die tweede herstel van die CK-slytplaat -komponent.

Na die voltooiing van 4803 uur in produksie (RC340gesigskop, saam met CK-slytplaat), het 'n geskatte 14 122,67 $\mathrm{kg}$ materiaal gevind wat nodig is om die komponent te herstel (JCB-Gearvest (Pty) Ltd, 2019).

Ondanks die feit dat minder materiaal benodig is om die standaard SV-slytplaat -komponente te herstel, het die voorlopige SOW aan die lig gebring dat die komponent byna $2484,79 \mathrm{~kg}$ aan strukturele herstelwerk benodig as gevolg van skade aan die vloerstruktuur tydens produksie. Die komponent wat met CK-slytplaat bedek is, benodig $809,62 \mathrm{~kg}$ strukturele herstelwerk, $2 \%$ meer as wat in die aanvanklike herstel vereis is.

\section{Materiaalanalise}

Die analise van die laboratoriumresultate en hoe dit vergelyk met wat tydens produksie waargeneem is en wat ondersoek is, is van kritieke belang om die uitkoms van die navorsing te ondersteun.
Die materiaal toets het ' $n$ ontleding van die meganiese eienskappe van beide die SV- en CK-slytplate ingesluit. 'n Ontleding van die chemiese samestelling van die SVslytplaat is gedoen, insluitend 'n tegniese verslag van die vergelykende sluitasievermoëns van beide monsters.

Die chemiese ontleding van beide die $20 \mathrm{~mm}$ en $30 \mathrm{~mm}$ CKslytplaatmonsters, monster A en monster B, het aan die lig gebring dat geen van die monsters se chemiese samestelling ooreenstem met die gespesifiseerde standaard nie, en met differensiële voldoening stem nie een van die monsters se oorspronklike materiaal sertifikate ooreen met die resultate nie van die chemiese ontleding.

Figuur 10 (monster A) en figuur 11 (monster B) illustreer die verskil tussen die elementskonsentrasie wat in die materiaalsertifikate gespesifiseer is en die elementskonsentrasie wat tydens laboratoriumtoetse verkry is.

Reeks 1 (blou) verteenwoordig die elementskonsentrasie -resultate wat tydens laboratoriumtoetse verkry is, en reeks 2 (rooi) verteenwoordig die elementkonsentrasie wat op die materiaalsertifikate gespesifiseer is.

Die vergelykings dui aan dat die koolstofkonsentrasie in monster A, aangedui deur die laboratoriumtoetse, ongeveer $68,75 \%$ meer is as gespesifiseer op die materiaalsertifikaat. Die groter hardheid van die materiaal, aangetoon in die laboratoriumresultate (Tabel 2), kan toegeskryf word aan die verhoogde koolstofvlakke in die materiaal. Die laboratoriumresultate het ook getoon dat monster A se uiteindelike treksterkte $29,55 \%$ meer is as gespesifiseer in die materiaalsertifikate.

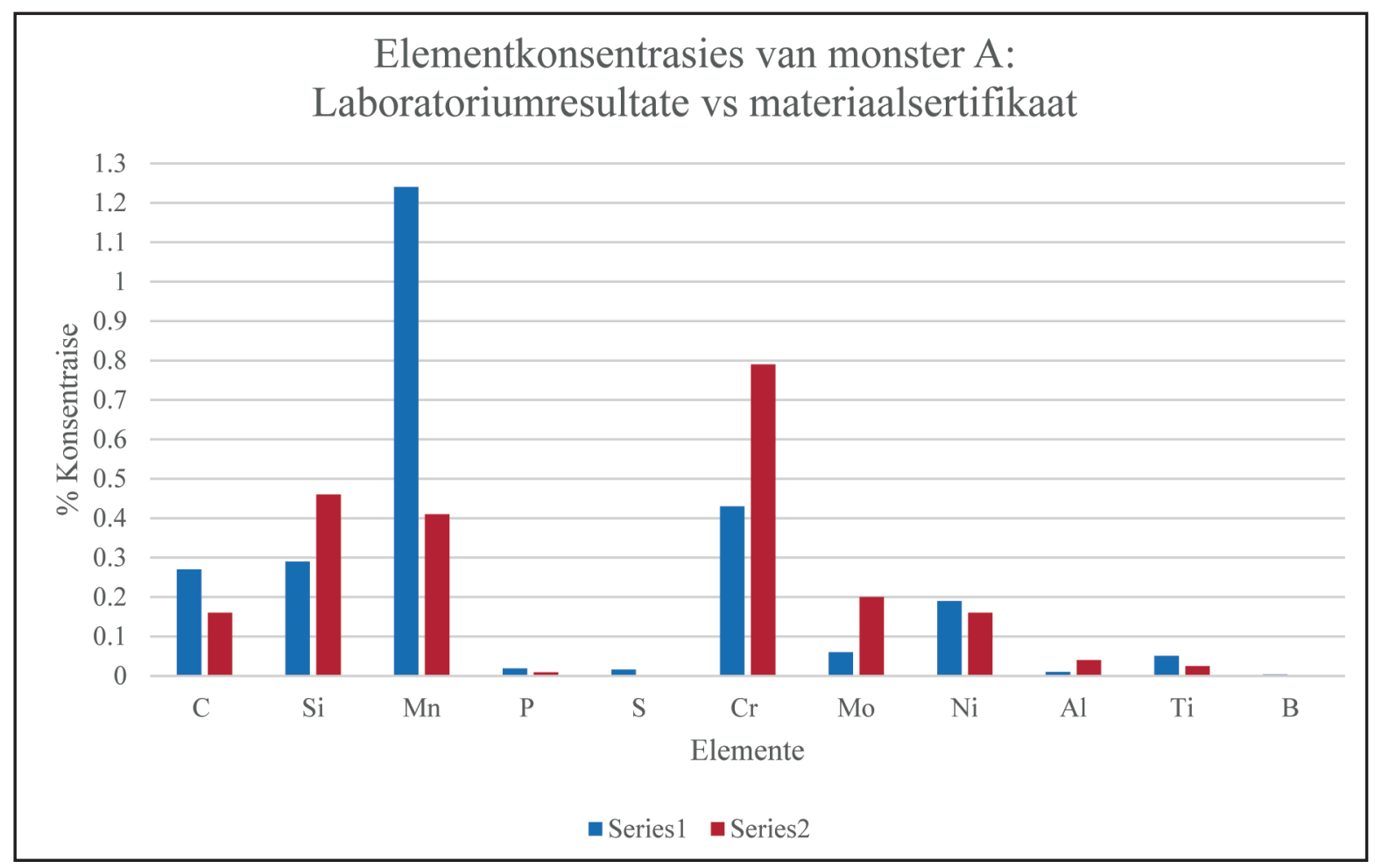

FIGUUR 10: Vergelyking van elementkonsentrasies van monster $A$ 
Monster B seelementkonsentrasie volgens die laboratoriumanalise, ge illustreer in Figuur 11, is ongeveer dieselfde as gespesifiseer in die materiaalsertifikate, met baie klein verskille. Alhoewel die hardheid wat op die materiaalsertifikaat gespesifiseer is nie presies dieselfde is as die hardheid bepaal met laboratoriumtoetse (Tabel 3) nie, val beide waardes binne die gespesifiseerde reikwydte. Die verskil tussen die laboratoriumresultate en die spesifikasie op die materiaalsertifikate was slegs $4,1 \%$.

Dit is nodig om 'n materiaal se voldoening aan die gestelde spesifikasie van die materiaalgraad te bevestig, aangesien 'n afwyking in die chemiese konsentrasie van kritiese elemente in die samestelling van die materiaal kan toeskryf

TABEL 2: Monster A: Laboratoriumtoetsresultate vir Meganiese Eienskappe

\begin{tabular}{|c|c|c|c|}
\hline \multicolumn{2}{|l|}{ Sertifikaatnr.: } & \multicolumn{2}{|l|}{ 20-0912-B } \\
\hline \multicolumn{2}{|l|}{ Plaatdikte: } & \multicolumn{2}{|l|}{$20 \mathrm{~mm}$} \\
\hline \multicolumn{2}{|l|}{ Materiaalspesifikasie } & \multicolumn{2}{|l|}{ TH400 } \\
\hline \multicolumn{2}{|l|}{ Toetsmetode } & \multicolumn{2}{|l|}{ ISO 6892-1, ISO 6506-1, ISO 148-1 } \\
\hline \multicolumn{2}{|l|}{ Toetsspesifikasievereistes } & Uiteindelike treksterkte (MPa) & 1350 \\
\hline \multicolumn{2}{|l|}{ Toetsspesifikasievereistes } & Hardheid (HBW) & $360-418$ \\
\hline Optimum belasting (kN) & Maksimum belasting (kN) & Uitbreiding $(\mathrm{mm})$ & Finale $\varnothing(\mathrm{mm})$ \\
\hline 122,7 & 131 & 4,9 & 7,3 \\
\hline Optimum druk (MPa) & Uiteindelike treksterkte (MPa) & Verlenging (\%) & Hardheid (HBW) \\
\hline 1590,8 & 1698,4 & 9,9 & 444 \\
\hline
\end{tabular}

(IMP Labs, 2020).

TABEL 3: Monster B: Laboratoriumtoetsresultate vir Meganiese Eienskappe

\begin{tabular}{|c|c|c|c|}
\hline \multicolumn{2}{|l|}{ Sertifikaatnr.: } & \multicolumn{2}{|l|}{ 20-0912-A } \\
\hline \multicolumn{2}{|l|}{ Plaatdikte: } & \multicolumn{2}{|l|}{$30 \mathrm{~mm}$} \\
\hline \multicolumn{2}{|l|}{ Materiaalspesifikasie } & \multicolumn{2}{|l|}{ TH400 } \\
\hline \multicolumn{2}{|l|}{ Toetsmetode } & \multicolumn{2}{|l|}{ ISO 6892-1, ISO 6506-1, ISO 148-1 } \\
\hline \multicolumn{2}{|l|}{ Toetsspesifikasievereistes } & Uiteindelike treksterkte (MPa) & 1350 \\
\hline \multicolumn{2}{|l|}{ Toetsspesifikasievereistes } & Hardheid (HBW) & $360-418$ \\
\hline Optimum belasting (kN) & Maksimum belasting (kN) & Uitbreiding (mm) & Finale $\emptyset(\mathrm{mm})$ \\
\hline 120,3 & 128,2 & 3,6 & 6,9 \\
\hline Optimum druk (MPa) & Uiteindelike treksterkte (MPa) & Verlenging (\%) & Hardheid (HBW) \\
\hline 1534,8 & 1635,9 & 7,2 & 388 \\
\hline
\end{tabular}

(IMP Labs, 2020).

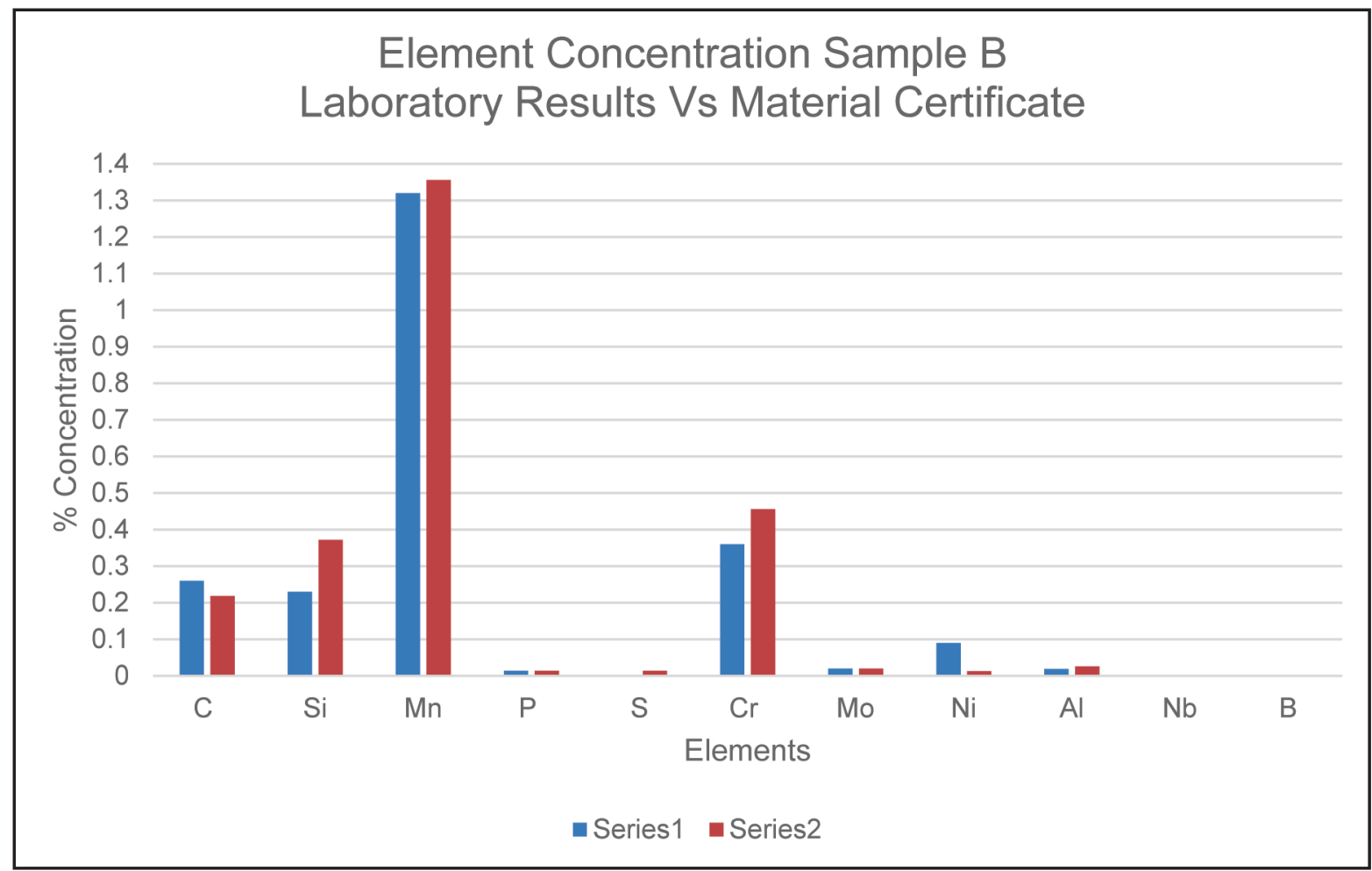

FIGURE 11: Vergelyking van elementkonsentrasies van monster B 
aan die verbeterde of verlaagde prestasie van die materiaal. Die tegniese waarnemings van die slytasie-eienskappe van skuurbestande staal en bedekkingsmateriaal het aangedui dat CK-plate, afhangende van die toepassing daarvan, ' $n$ hoër slytweerstand het as standaardvoeringplate. Die probleem is egter dat CK-materiaal in sones waar dit blootgestel word aan 'n skok-impak vatbaar is vir aansienlike slytasie sodra dit begin versplinter. Verder is bevind dat CK-plate sigbare lae het (Carter, 2020). Hierdie bevindings stem ooreen met die waarnemings van die velddiensspan tydens produksie en wat met nadere ondersoeke getoon het dat die samesmeltingslaag van die basismateriaal en die CK-neerslag by inspeksie sigbaar was.

Laboratoriumtoetse en mikrostruktuurevaluerings geillustreer in Figuur 12, toon duidelik die susbstraatlaag met twee bedekkingslae met verskillende samestellings en mikrostrukture. Carter het bevind dat die bedekking op die saamgestelde slytplaat in twee fases gedeponeer is. Die ontleding van die geëtste Nital-2 op vergrotings van $20 \mu \mathrm{m}$ skaal foto's het die tussenlaag tussen die substraat en die oorlaag aangedui (Carter, 2020).

\section{Materiaalkoste-analise}

Op grond van die data-analise van die materiaalkosteberamings wil dit aanvanklink voorkom asof dit meer koste-effektief is om die komponent te herbeklee met 'n standaard SV-slytpakket. Volgens Borox Wear Parts (Edms.) Bpk. was die materiaalkoste vir herbekleding met die saamgestelde CK-slytplate R805 995,90 en R 430 505,10 vir herbekleding met SV-slytplate (Borox Wear Parts (Pty) Ltd, 2018). Dus is die standaardkoste vir die laaibak van 'n RH340 voorlaaier ongeveer 46,59\% minder met die gebruik van standaardvoeringplate, in plaas van saamgestelde CKslytplate. Herbekleding met saamgestelde CK-slytplate is dus byna 1,87 keer duurder as herbekleding met standaardslytplate.

Duidelik moet die produksie-doeltreffendheid van die CKbeklede komponent proporsioneel toeneem om die bykomende herstelkoste te regverdig. Die koste van die komponente moet dus vergelyk word in terme van produksie-doeltreffendheid om 'n omvattende oorsig te kry van die algehele en materiële koste van die CK-slytplate.
Die materiaalkoste-ontleding het aangedui dat herbekleding met SV-slytplate R 32,20/ kg kos teenoor R63,51/ kg met CK-slytplate. Die materiaalkoste van die CK-slytplaat word egter bereken op grond van die oppervlakte van die na-mate-gesnyde-dele benodig vir herbekleding, in teenstelling met SV-slytplaat wat bereken word op grond van die massa van die na-mate-gesnyde-dele. Die bedryfskoste van die materiaal wat gebruik is, word dus eerder bereken op grond van die materiaalkoste per produksie-uur wat die herbeklede komponent kon handhaaf.

Die bedryfskoste per uur is ongeveer R 93,06/h vir die SVplate en R 167,81/h vir die CK-plate. Dus is die CK-plate ongeveer $80 \%$ duurder in terme van materiaalkoste per produksie-uur. Hierdie tariefberekening gee 'n aanduiding van die koste van die materiaal benodig vir herstelwerk wat heeltemal afhanklik is van die produksie-ure wat die komponent onderhou. Dus, hoe langer die komponent in produksie kan bly voordat dit weer herstelwerk nodig het, hoe goedkoper word die materiaalkoste.

Op grond van die voorlopige inventaris van werk was die totale geskatte materiaalkoste R 311 341,47 vir die tweede herbekleding van die laaibak toegerus met standaard SVslytplate, vir ongeveer $10 \quad 650,95 \mathrm{~kg}$ materiaal. Die ooreenstemende waardes vir die laaibak herstel met saamgestelde CK-slytplate was R 385 070,43, vir ongeveer 14 122,67 kg materiaal (JCB-Gearvest (Pty) Ltd, 2019).

Aanvanklik wou dit voorkom asof die laaibak toegerus met CK-slytplate meer materiaal vir herstelwerk sou benodig en dat herstelwerk dus duurder sou wees. Die koste-analise van die tweede rondte herstelwerk het egter getoon dat die herstelkoste vir CK-slytplate $7,18 \%$ laer was as die geraamde herstelkoste vir die laaibak toegerus met SVslytplate.

Alhoewel die kosteraming vir die materiaal aangedui het dat die saamgestelde CK-slytplaat die struktuurplate van die laaibak nie noodwendig beter beskerm het as die standaard SV-slytplate nie, het die laaibak wat met CKslytplate herstel is, minder strukturele skade opgedoen as dié wat met SV-slytplate herstel is.

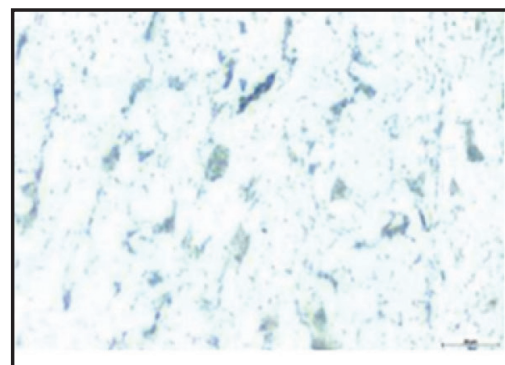

(a)

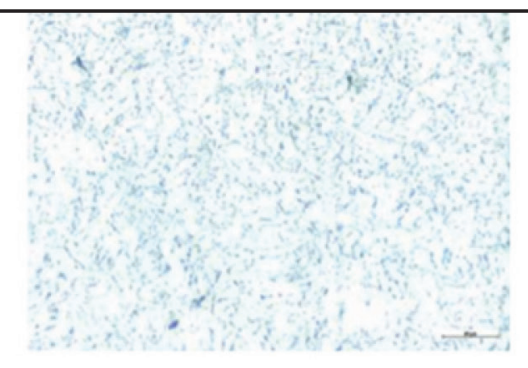

(b)

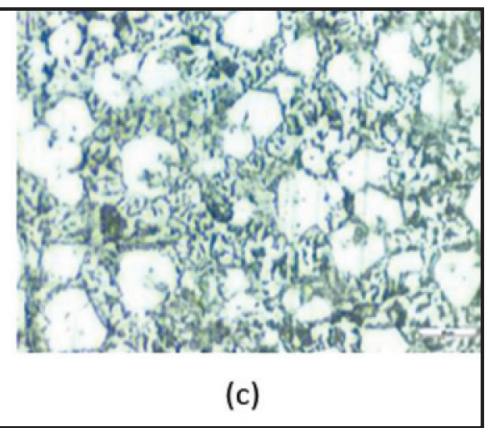

(c)

FIGUUR 12: CK -monsterevaluering: (a) substraatmikrostruktuur van ferriet en perliet, (b) tussenlaagmikrostruktuur van ferriet en karbiede, (c) oorlaagmikrostruktuur van dik karbiede en perliet (Carter, 2020). 


\section{Gevolgtrekking}

Hierdie studie lei tot sekere gevolgrekkings op grond van waarnemings op die voorlaaiers in produksie en in die werkswinkel, in samevatting met teoretiese navorsing aan die hand van die literatuuroorsig, en in ag genome die resultate van metallurgiese materiaaltoetse. Die eerste gevolgtrekkig is dat saamgestelde CK-slytplate die gewenste minimum aantal produksie-ure voldoende oorskry terwyl dit' $n$ aansienlike slytweerstand toon. Aan die ander kant is die materiaalkoste gemeet in terme van produksieure effens hoër as 3500 ure in produksiedié van standaard SV-slytplate. Samevattend kan die gebruik van saamgestelde CK-slytplate aanbeveel word as 'n lewensvatbare alternatief.

Die studie dui ook aan dat voorlaaiers toegerus met CKslytplate 'n verhoogde dravermoë het. Die marginale afname in die massa van die slytpakket en die moontlike toename in produksiedoeltreffendheid of -uitset versterk dus die motivering vir die gebruik van CK-slytplate as 'n geskikte alternatief vir standaard SV-plate.

Bogenoemde gevolgtrekkings word ondersteun deur die volgende oorwegings:

Vanuit 'n ekonomiese oogpunt kan dit van kritieke belang wees dat die verwagte minimum produksie-ure bereik word en kan selfs belangriker wees as die blote kosteverhoudings van herstelwerk. Die $250 \%$ variasie in die aantal produksie-ure met gebruik van standaard SV-slytplate lei tot ' $n$ aansienlike verhoging van die risiko om sake te doen en van die risiko vir moontlike verlies aan saamgestelde produksie en omset. Die materiaaleienskappe van die standaard voeringplate blyk nie gewaarborg te wees wanneer 4328 produksie-ure oorskry word nie.

Vervolgens kan dit beteken dat die voorlaaier met standaard SV-slytplate moontlik vir langer tye uit produksie onttrek moet word vir herstelwerk, en 'n laer produksiesiklus kan handhaaf. Dit kan sakebeplanning en produksieverkope beïnvloed, en kan 'n onvoorspelbare produksie-faktor word as gevolg van die variasie van $250 \%$ en die enkele waarneming van CK-werkverrigting. Dit kan 'n verdere studie uit ' $n$ besigheidsoogpunt vereis en nie noodwendig vanuit ' $n$ fokus op meganiese eienskappe nie.

Die saamgevatte studieresultate gee ook 'n duidelike aanduiding dat ' $n$ kombinasie van saamgestlede CK- en standard SV-slytplate verdere oorweging regverdig, met spesifieke verwysing na ligging en plaatoriëntasie vir die doeleindes van skokbreking en weerstand teen slytasie.

Hierdie studie is wel gebaseer is op die bekleding van 'n enkele voorlaaier met CK-slytplate, maar die waarneming van kritieke swigprobleme, soos delaminasie, is belangrik. Dit is ook belangrik om in gedagte te hou dat hierdie swigprobleme mettertyd met meer ervaring op die verskaffersvlak voorkom kan word, wat ook leweringstyd aansienlik kan verkort.

\section{Verwysings}

Aggregates Business. (2012). Backhoe or front shovel choice. Retrieved July 10 2020, from https://www.aggbusiness.com/ab1/feature/backhoe-or-frontshovel-choice.

ASGCO. (2020). Chromium Carbide Overlay (CCO) Wear Plate. Retrieved July 06, 2020, from https://www.asgco.com/products/chromium-carbide-overlay-ccoplate/.

AZoM. (2018). Abrasion-Resistant Steel: Properties and Applications. Retrieved July 05, 2020, from https://www.azom.com/article.aspx?ArticlelD=17086\#: :tex $\mathrm{t}=$ Abrasion\%2Dresistant\%20(AR)\%20steel,to\%20the\%20addition\%20of\%20 carbon.

Barnes, N., Borle, S., Dewar, M., Andreiuk, J., Mendez, P.F. (2014). 3D microstructure reconstruction of chrome. Science and Technology of Welding and Joining, 696-702. https://doi.org/10.1179/1362171814Y.0000000244.

Borox International AB. (2020). Other Products. Retrieved from Borox: https:// www.borox.se/en/products/other-products.

Borox Wear Parts (Pty) Ltd. (2018). 017BRX-0106 Material Cost Estimate Front Jaw 3 W. Edenvale: Borox.

Borox Wear Parts (Pty) Ltd. (2018). Terrex RH340 face shovel FS107 3 G front jaw overlay and standard cost estimate. Edenvale.

Borox Wear Parts (Pty) Ltd. (2020). 006BRX-146 Lifespan Analysis. Limpopo, Mokopane.

Carter, T.J. (2020). Technical Note (TN 20-0912) Comparison of Wear Properties of Abrasion-Resistant Steel and Overlay Coating. Benoni: IMP Labs Material Testing Laboratory.

Chintha, A.R. (2019). Metallurgical aspects of steels designed to resist abrasion and. Materials Science and Technology, 35(10), 1133-1148. https://doi.org/10 .1080/02670836.2019.1615669.

CS Wear Resistant Material Co., Ltd. (2020). Chrome Carbide Overlay Plate. Retrieved from CSWresource: http://cswresource.com/list/18-Chromium Carbide-Overlay.html.

Esser, F., Vliegenthart, R. (2017). The International Encyclopedia of Communication Research Methods. Comparative Research Methods, p. 02. https://doi. org/10.1002/9781118901731.iecrm0035.

IMP Labs. (2020). Document ID: QSP 7.8-TC01 - Certificate No.: 20-0912-A. Benoni: IMP Labs.

IMP Labs. (2020). Document ID: QSP 7.8-TC01 - Certificate No.: 20-0912B. Benoni: IMP Labs.

Jadco. (2019). How to compare heat treated wear resistant steels. Retrieved August 31, 2020, from https://www.jadcomfg.com/blog/post/how-to-compare-heattreated-wear-resistant-steels.

JCB-Gearvest (Pty) Ltd. (2018). 017BRX-0105 RH340 3G TH400 and overlay weight and cost estimates front jaw. Onderstepoort.

JCB-Gearvest (Pty) Ltd. (2018). RH340 3G FS107 Face shovel repair process data book Photos. Onderstepoort.

JCB-Gearvest (Pty) Ltd. (2019). 006BRX-8701 3W Field service report and photos. Mokopane, Limpopo: Field Service Department.

JCB-Gearvest (Pty) Ltd. (2019). 006BRX-8702 3G Field service report and photos. Mokpane, Limpopo: Field Service Department.

JCB-Gearvest (Pty) Ltd. (2019). 017BRX-0109 RH340 3S FS107 Preliminary SOW and cost estimation. Mokopane.

JCB-Gearvest (Pty) Ltd. (2019). 017BRX-0110 RH340 3E FS112 Preliminary SOW and cost estimation. Mokopane.

JCB-Gearvest (Pty) Ltd. (2020). Building and Refurbishment of Earthmoving Buckets and Load Bowls. Retrieved August 24, 2020, from http://gearvest.co.za/wpcontent/uploads/2019/02/gallery1-new.jpg.

Jing, L., Rangasayee, K., Minghao, S., Leijun, L. (2020). Solidified Microstructure of Wear-Resistant Fe-Cr-C-B Overlays. The Minerals, Metals \& Materials Society and ASM International, 51(B), 1291-1300. https://doi.org/10.1007/s11663020-01863-3.

Klimpel, A., Gorka, J., Czuprynski, A. (2006). Comparison of chromium cast iron. Journal of Achievements in Materials and Manufacturing Engineering, 18(12), 387-390.

Njini, F. (2020). Platinum giant says lockdown risks killing mines. News24 - Fin24.

Pei, Y.C., Xia, D.X., Cong, L., et al. (2020). Comparison of sliding wear properties of 400 grade low alloy wear-resistant steels with different microstructure. Materials $899 \times / 727 / 1 / 012002$.

Precision Grinding. (2016). Wear Plates and Abrasion Resistant Steel Parts. Retrieved February 10, 2020, from https://precisiongrinding.com/customsteel-plate/wear-plates-abrasion-resistant-steel-parts/.

Resource Centre. (2016). Mixed Methods Research. Retrieved February 10, 2020, from http://resourcecentre.foodrisc.org/mixed-methods-research_185.html.

Varenberg, M. (2013). Towards a unified classification of wear. Friction, 1(4), 330340. https://doi.org/10.1007/s40544-013-0027-x.

Waldun. (2020). Chromium Carbide Wear Plate. Retrieved from Hard Facing Fty: https://www.hardfacingfty.com/chromium-carbide-overlay-plate/\#tab-id-2.

Welding Alloys Group. (2020). WA Integra ${ }^{\mathrm{TM}}$ Workshop and Plate Processing Manual. Retrieved July 07, 2020, from https://www.welding-alloys.com/uploads/pdf/ brochures/en/wa-integra/workshop-and-plate-processing-manual.pdf. 